\title{
Correction to: Genetic polymorphism of IDOL gene was associated with the susceptibility of coronary artery disease in Han population in Xinjiang, China
}

Dilare Adi ${ }^{1,2 \dagger}$, Jialin Abuzhalihan ${ }^{1,2+}$, Jing Tao ${ }^{1,3}$, Yun Wu ${ }^{4}$, Ying-Hong Wang ${ }^{5}$, Fen Liu ${ }^{6}$, Yi-Ning Yang ${ }^{1,2}$, Xiang $\mathrm{Ma}^{1,2}$, Xiao-Mei $\mathrm{Li}^{1,2}$, Xiang Xie ${ }^{1,2}$, Zhen-Yan Fu ${ }^{1,2}$ and $\mathrm{Yi}_{\text {-Tong }} \mathrm{Ma}^{1,2^{*}}$

Correction to: Hereditas 158, 12 (2021)

https://doi.org/10.1186/s41065-021-00178-w

Following the publication of the original article [1], it was noted that the following equal contribution note was missing.

Dilare Adi and Jialin Abuzhalihan contributed equally to this work.

The original article has been updated.

\section{Author details}

'Department of Cardiology, First Affiliated Hospital of Xinjiang Medical University, Urumqi 830054, PR China. ${ }^{2}$ Xinjiang Key Laboratory of Cardiovascular Disease Research, Urumqi 830054, PR China. ${ }^{3}$ People's Hospital of Xinjiang Uygur Autonomous Region, Urumai 830001, PR China. ${ }^{4}$ Department of General Practice, First Affiliated Hospital of Xinjiang Medical University, Urumqi 830054, PR China. ${ }^{5}$ Health Checkup Department of The First Affiliated Hospital of Xinjiang Medical University, Urumqi 830054, PR China. ${ }^{6}$ State Key Laboratory of Pathogenesis, Prevention and Treatment of High Incidence Diseases in Central Asia, Clinical Medical Research Institute, the First Affiliated Hospital of Xinjiang Medical University, Urumqi 830054, PR China.

Published online: 05 June 2021

\section{Reference}

1. Adi D, Abuzhalihan J, Tao J, et al. Genetic polymorphism of IDOL gene was associated with the susceptibility of coronary artery disease in Han population in Xinjiang, China. Hereditas. 2021;158:12.https://doi.org/10. 1186/s41065-021-00178-w.

The original article can be found online at https://doi.org/10.1186/s41065021-00178-w.

*Correspondence: myt_xj@sina.com

${ }^{\dagger}$ Dilare Adi and Jialin Abuzhalihan contributed equally to this work.

${ }^{2}$ Xinjiang Key Laboratory of Cardiovascular Disease Research, Urumqi 830054, PR China

Full list of author information is available at the end of the article

(c) The Author(s) 2021. Open Access This article is licensed under a Creative Commons Attribution 4.0 International License, which permits use, sharing, adaptation, distribution and reproduction in any medium or format, as long as you give appropriate credit to the original author(s) and the source, provide a link to the Creative Commons licence, and indicate if changes were made. The images or other third party material in this article are included in the article's Creative Commons licence, unless indicated otherwise in a credit line to the material. If material is not included in the article's Creative Commons licence and your intended use is not permitted by statutory regulation or exceeds the permitted use, you will need to obtain permission directly from the copyright holder. To view a copy of this licence, visit http://creativecommons.org/licenses/by/4.0/. The Creative Commons Public Domain Dedication waiver (http://creativeco mmons.org/publicdomain/zero/1.0/) applies to the data made available in this article, unless otherwise stated in a credit line to the data. 